\title{
Skal legemiddelfirmaene bestemme hvilke studier som blir gjort?
}

\author{
Kun legemidler som i randomiserte, kontrollerte studier er vist å være bedre enn placebo, blir godkjent av \\ legemiddelverkene. Legemiddelfirmaene synes å la profitten avgjøre hvilke legemidler studiene skal utføres \\ på. Det blokkerer for rask utvikling og godkjenning av de mest effektive midlene.
}

Legemiddelfirmaene lager protokollene for praktisk talt alle de kostbare randomiserte, kontrollerte studiene og betaler offentlige sykehusavdelinger og private organisasjoner for å utføre dem for seg $(1,2)$. Firmaene kan prioritere de legemidlene som gir høyest avkastning i patenttiden på 15-20 år og nedprioritere livsviktige legemidler $(1,3)$.

Food and Drug Administration, European Medicines Agency og Statens legemiddelverk godkjenner praktisk talt kun legemidler som har vist effekt i randomiserte, kontrollerte studier, til tross for en tydelig kommersiell skjevhet (1). Dette er i praksis godkjenningsmyndighetenes viktigste rettesnor for legemiddelbehandling.

Et aktuelt eksempel er bremsemedisinbehandling av atakkvis multippel sklerose. Legemiddelfirmaer har hatt høy avkastning på bremsemedisiner siden den første ble godkjent internasjonalt i 1993. Behandlingsstudier har siden 2001 tydet på at stamcelletransplantasjon kan stanse multippel sklerose (4), men randomiserte, kontrollerte studier mangler fordi stamcelletransplantasjon ikke er kommersielt interessant for industrien - patentene på cellegiftene er utløpt. Nå planlegges en offentlig norsk randomisert, kontrollert studie, men finansiering mangler.

\section{Forskriving utenfor indikasjon}

Et godkjent legemiddel kan forskrives utenfor godkjent indikasjon når det foreligger medisinsk grunnlag. Svenske nevrologers behandlingsstudier med rituksimab (MabThera) tyder på god effekt mot multippel sklerose, og de har derfor forskrevet midlet utenfor godkjent indikasjon $(5,6)$.

Rituksimab viste god effekt mot attakkvis multippel sklerose $\mathrm{i}$ fase 2-studier, men Roche gikk ikke videre med randomiserte, kontrollerte studier (fase 3-studier), sannsynligvis fordi deres patent på ritutuksimab utløp i $2015(6,7)$. Firmaet presser nå svenske helsemyndigheter for å stanse forskrivning av rituksimab utenfor indikasjon, sannsynligvis fordi deres patenterte bremsemedisin ocrelizumab snart blir godkjent (7).

Ocrelizumab er nesten identisk med rituksimab og sannsynligvis en patentforlenger, et eksempel på evigblomstring (evergreening) - patentering av et nytt legemiddel som kun representerer en liten modifikasjon av et gammelt $(7,8)$. I 2010 avbrøt Roche randomiserte, kontrollerte studier på ocrelizumab mot revmatoid artritt og lupus erythematosus på grunn av infeksjoner med dødsfall. Rituksimab har en bedre bivirkningsprofil (9).

Roche viste nylig i en randomisert, kontrollert studie at ocrelizumab har god effekt mot attakkvis multippel sklerose (10). Ocreluzimab har sannsynligvis ikke bedre effekt enn rituksimab, men gir langt høyere avkastning. Nå blir ocrelizumab godkjent og Roche starter prisforhandlinger - $\mathrm{i}$ Norge med Helseforetakenes innkjøpsservice (HINAS).

\section{Hemmelige prisforhandlinger med legemiddelfirmaene}

Våren 2016, etter henvendelse fra legemiddelfirmaer, varslet lederen for Helseforetakenes innkjøpsservice at prisforhandlingene med firmaene og legemiddelprisene juridisk sett var forretningshemmeligheter (11). Endringen ble kritisert av blant annet Legemiddelinnkjøpssamarbeidet og sendt ut på høring. Alle høringssvarene, unntatt tre - blant annet det fra Legemiddelindustrien - var negative og understreket viktigheten av transparens, i tråd med internasjonale anbefalinger $(3,12)$. Direktørene for de regionale helseforetakene skal snart fatte sin beslutning.

Legemiddelfirmaer kjøper seg politisk og medisinsk innflytelse, aller mest i medisinskfaglig ledende land som USA, Tyskland, Frankrike, Sveits og England (13). Godkjenningsmyndighetene kan påvirkes European Medicines Agency er avhengig av inntekter fra disse firmaene - slik at firmaene blant annet oppnår høyere legemiddelpriser $(2,3,14)$. I år offentliggjorde norsk helsepersonell for første gang honorarer fra legemiddelfirmaer, men kun for 2015 (15). En toneangivende nevrolog innen feltet multippel sklerose oppga 170000 kroner. Deltagelsen var frivillig, en tredel deltok ikke, og de oppgitte beløpene ble ikke kontrollert.

Det er uforsvarlig at legemiddelfirmaene praktisk talt har eneansvar for utvelgelse av på hvilke legemidler randomiserte, kontrollerte studier skal utføres og for finansiering og styring av studiene. Pasientene kan få rimeligere og bedre legemidler raskere hvis politikere og leger sørger for ansvarlig regulering (14). De nordiske landene kan for eksempel opprette et felles offentlig legemiddelfirma.

\section{Sigbjørn Rogne}

sigrogne@online.no
Sigbjørn Rogne (f. 1965) er spesialist i geriatri og fordøyelsessykdommer.

Forfatter har fylt ut ICMJE-skjemaet og oppgir følgende interessekonflikt: Han har multippel sklerose og fikk stamcelletransplantasjon ved universitetssykehuset i Firenze i januar 2015.

\section{Litteratur}

1. Stamatakis E, Weiler R, Ioannidis JPA. Undue industry influences that distort healthcare research, strategy, expenditure and practice: a review. Eur J Clin Invest 2013; 43: 469-75.

2. Abraham J, Bardelay D, Kopp C et al. Education and debate: Making regulation responsive to commercial interests: streamlining drug industry watchdogs. BMJ 2002; 325: 1164-9.

3. Ghinea N, Lipworth W, Kerridge I. Propaganda or the cost of innovation? Challenging the high price of new drugs. BMJ 2016; 352: i1284.

4. Burt RK, Balabanov R, Han X et al. Association of nonmyeloablative hematopoietic stem cell trans plantation with neurological disability in patients with relapsing-remitting multiple sclerosis. JAMA 2015: 313: 275-84

5. Alping P. Frisell T, Novakova $L$ et al. Rituximab versus fingolimod after natalizumab in multiple sclerosis patients. Ann Neurol 2016; 79: 950-8.

6. Salzer J, Svenningsson R, Alping P et al. Rituximab in multiple sclerosis: A retrospective observationa study on safety and efficacy. Neurology 2016; 87 : 2074-81.

7. Svenningsson A. MS-läkare: Bolag vill diktera val av behandling. Svenska Dagbladet 2016.

8. Collier R. Drug patents: the evergreening problem CMAJ 2013; 185: E385-6.

9. Ramos-Casals M, Sanz I, Bosch X et al. B-celldepleting therapy in systemic lupus erythematosus. Am J Med 2012; 125: 327-36.

10. Hauser SL, Bar-Or A, Comi G et al. Ocrelizumab versus Interferon Beta-1a in Relapsing Multiple Sclerosis. N Engl J Med 2016. E-publisert 21.12.2016.

11. Bordvik M. Krav om hemmelighold vekker reaksjoner. Dagens Medisin 28.4.2016. https://www.dagensmedisin.no/artikler/2016/04/28/ krav-om-hemmelige-priser-vekker-reaksjoner/ (9.1.2017).

12. Bordvik M. «Høyere priser, svekket legetillit og økt korrupsjonsfare». Dagens Medisin 5.12.2016. https://www.dagensmedisin.no/artikler/2016/12/ 05/hoyere-priser-svekket-tillit-til-helsepersonellog-okt-korrupsjonsfare/ (9.1.2017).

13. Stiglitz JE. The Prize of Inequality. New York: W. W. Norton \& Company, 2012

14. Garattini S, Bertele' V. How can we regulate medicines better? BMJ 2007; 335: 803-5

15. Bordvik M. Engen $\emptyset B$. Se hvem som fikk honorarer i fjor. Dagens Medisin 11.8.2016

https://www.dagensmedisin.no/artikler/2016/08/ $11 /$ sok-i-listen-over-utbetalinger/ (9.1.2017).

Mottatt 31.12. 2016, første revisjon innsendt 6.1. 2017, godkjent 10.1. 2017. Redaktør: Ketil Slagstad. Engelsk oversettelse på www.tidsskriftet.no

Publisert først på nett. 